\title{
Prosthetic rehabilitation for a patient with CO-MI discrepancy
}

\author{
Seung-Sik Choo, Yoon-Hyuk Heo, Lee-Ra Cho, Chan-Jin Park* \\ Department of Prosthodontics and Research Institute of Oral Science \\ College of Dentistry, Gangneung-Wonju National University, Gangneung, Republic of Korea
}

Centric occlusion-maximum intercuspation (CO-MI) discrepancy is one of main causes of evoking premature contact and resultant mandibular shift. These non-physiological conditions can induce temporomandibular disease, periodontitis, and non-carious cervical lesion. Therefore, if CO-MI discrepancy exists in patients who need extensive prosthetic rehabilitation, it must be corrected and then physiological occlusion must be restored. This report describes the treatment procedure of removing CO-MI discrepancy and prosthetic rehabilitation in a patient with $3.5 \mathrm{~mm}$ discrepancy, multiple caries and periodontitis. Proper mandibular position and modified opening \& closing movement were confirmed by ARCUSdigma II and transcranial radiograph. (J Dent Rehabil Appl Sci 2015;31(3):273-82)

Key words: centric relation; maximum intercuspal position; centric slide; prosthetic rehabilitation

\section{서론}

편향된 교합 접촉(deflective occlusal contact)은 하 악운동이 의도된 경로에서 벗어나게 만드는 치아접촉 ${ }^{1}$ 을 말하며 중심위와 최대교두감합위의 불일치(CO-MI discrepancy)로 인하여 발생할 수 있다. 중심위와 최대교 두감합위의 불일치는 사면활주(centric slide), 조기접촉 (premature contact), 방해교합접촉(interceptive occlusal contact) 등의 여러가지 비생리적인 교합 양상을 일으키 고 구강악안면 영역에 다양한 문제를 초래할 수 있다.

Pullinger 등의 ${ }^{2}$ 연구에서 사면활주와 관련된 턱관절장 애의 유병률 조사에 따르면 0-1 $\mathrm{mm}$ 범위의 사면활주 는 환자군과 정상집단에서 비슷한 비율로 관찰되었으나 $2 \mathrm{~mm}$ 이상의 사면활주는 정상집단에서 단지 $6 \%$ 만이 관 찰되었고 $3 \mathrm{~mm}$ 이상의 사면활주는 대부분 환자군에서 만 관찰되어 “정상” 의 의미에 $2 \mathrm{~mm}$ 이내의 사면 활주가

*Correspondence to: Chan-Jin Park

Professor, Department of Prosthodontics, College of Dentistry, Gangneung-Wonju National University, 7, Jukheon-gil, Gangneung, 25457, Republic of Korea

Tel: +82-33-640-3153, Fax: +82-33-640-3103, E-mail: doctorcj@gwnu.ac.kr

Received: June 29, 2015/Last Revision: June 30, 2015/Accepted: July 14, 2015
포함되어야 한다고 제안했다. 이와 같은 결과는 일정범 위의 중심위와 최대교두감합위의 불일치가 병적 증상을 일으킨다는 사실을 제시하는 한편 개인의 생리적 적응능 에 따라 그 범위에 차이가 있음을 암시한다. 또 다른 연 구에서는 $2 \mathrm{~mm}$ 이상의 사면활주를 가진 집단에서 턱관 절 장애 유병률이 약 2.6배 증가하였다고 보고하였다. ${ }^{3}$

중심위와 최대교두감합위의 불일치는 턱관절 장애뿐 아니라 구강악안면 영역의 다양한 질병과 관련한다. 치 주질환의 심도가 깊어질수록 조기접촉의 빈도가 증가하 거나, ${ }^{4}$ 사면활주의 양이 증가할수록 치주낭 깊이가 증가 ${ }^{5}$ 한다고 밝힌 최근의 연구들이 있으며, 비우식성 치경부 병소를 가진 집단의 $53 \%$ 에서 방해교합접촉이 존재함이 밝혀졌다. 또한 $3 \mathrm{~mm}$ 이상의 사면활주를 가진 집단에 서 두통의 위험성이 약 25.9배 증가한다고 보고되었다. ${ }^{7}$

따라서 중심위와 최대교두감합위의 불일치가 과도 하고 이와 관련된 병적인 증상이 관찰되는 경우 교합

Copyright@ 2015 The Korean Academy of Stomatognathic Function and Occlusion. (c) It is identical to Creative Commons Non-Commercial License. 
치료를 고려해야만 한다. 치료목표는 중심위와 최대교 두감합위를 일치시키는 것이며 불일치의 정도나 임상 적 증상에 따라 교합조정이나 보철수복을 시행할 수 있다. 교합치료 후 편향된 교합 접촉, 사면활주, 조기 접촉 등의 제거를 확인해야 하며, 치료 후에 최대교두 감합위에서의 하악과두 위치와 개폐구경로의 변화가 나타날 수 있다. 이러한 변화양상은 경두개방사선 사 진과 ARCUSdigma II ( $\mathrm{KaVo}$ Dental GmbH, Biberach, Germany) 등의 진단기구를 통하여 관찰 가능하다.

Gnathology 학파에서는 과거 자연치열에서 중심위와 최대교두감합위의 불일치를 병적인 상태로 간주하였으 나 오류임이 검증되었고, PMS 학파에서는 일정 범위의 자유영역을 설정하였지만 그 범위는 점차 축소되었다. 다만, 광범위한 보철수복을 통한 교합재구성을 시행할 때 중심위와 최대교두감합위를 일치시켜, 하악운동의 자유로움, 치주조직의 건강, 안정적인 악관절과 교합, 건 전한 치아, 환자의 편안감, 적절한 심미성이 수복의 최 종목표가 되었다. ${ }^{8}$ 본 증례는 과거의 부적절한 보철수복 때문에 발생한 중심위와 최대교두감합위의 불일치가 나 타난 환자에서 광범위한 보철수복을 통해 조화로운 교 합을 회복한 경우로 이를 보고하고자 한다.

\section{증례 보고}

\section{1. 과거 병력 및 구강 검사}

54세 여성 환자로 이가 흔들리고 아프다는 주소로 내 원하였다. 주목할 만한 전신병력은 없었으나, 약간의 두 통을 호소하였다. 구강내 소견 및 방사선 사진 검사(Fig. 1)에서 좌측 상악 구치부의 심한 치조골 소실과 상하악 전치부의 이차우식이 관찰되어 보철물 제거 및 발거를 시행하였다. 발거 및 치주치료 후(Fig. 2) 우측 구치부는 급격한 스피만곡 및 치은퇴축으로 인하여 보철물의 재 제작이 필요한 상태였다. 보철물 재제작시 우측 상악 제

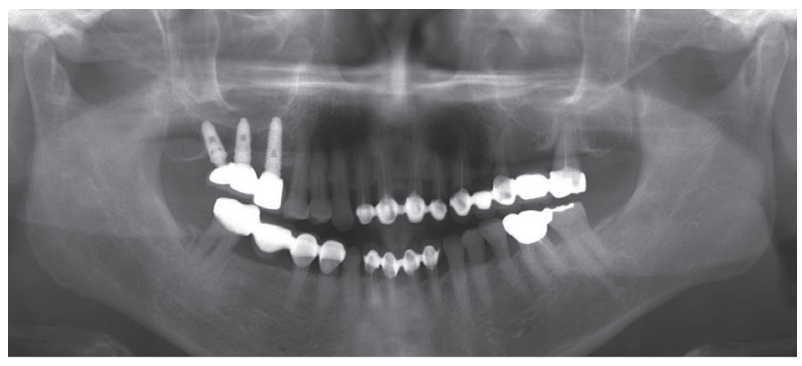

Fig. 1. Radiographic evaluation: severe bone loss and secondary caries on upper left quadrant.
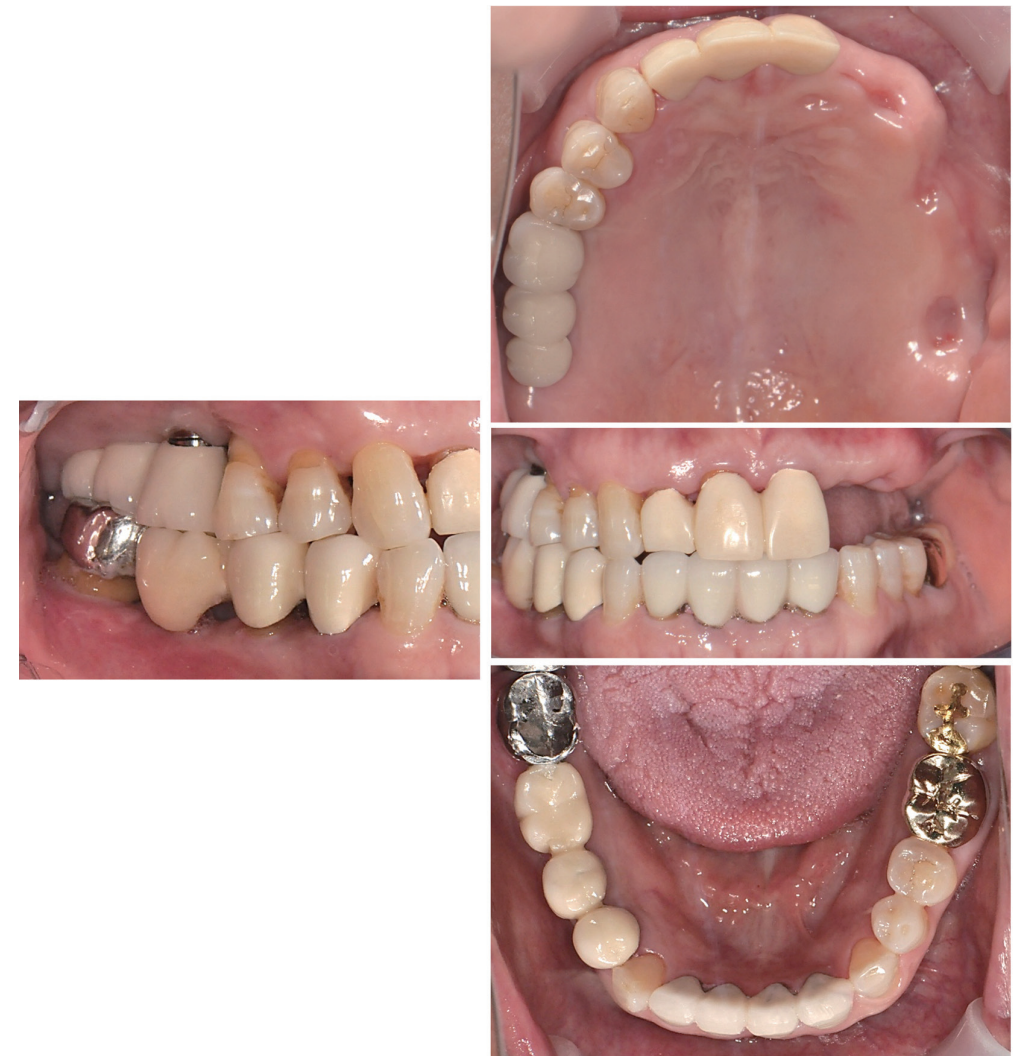

Fig. 2. Intraoral examination: multiple teeth loss, gingival recession and midline discrepancy. 
3대구치 부위의 근심경사되어 식립된 임플란트는 플렛 폼의 위치가 과하게 근접하고 축의 불일치가 심하여 상 부보철물을 제작하지 않기로 하였다.

또한 최대교두감합위에서 상하악 전치부 중심선의 불 일치를 관찰할 수 있었다(Fig. 3A). 이는 중심위(Fig. 3B) 와 비교 시 우측으로 약 $3.5 \mathrm{~mm}$ 편위된 상태였으며, 상 악 우측 측절치의 비심미적인 외형과 좌측 상악 구치부 의 치주질환은 이러한 중심위와 최대교두감합위의 불일 치 때문에 유발되었으리라 추측되었다. 환자는 이전 보 철수복 후 항상 옆으로 무는 듯한 느낌이었다고 진술했 으며 이전에 보철 수복시 대합되는 자연치를 많이 삭제 했었다는 사실을 기억하고 있었다. 이전 보철수복에 대 한 환자의 경험을 청취한 결과 부적절한 과거의 광범위 한 보철 수복 때문에 중심위와 최대교두감합위의 불일 치가 발생한 것으로 추측되었다. 과두위치와 개폐구경 로상의 사면활주를 관찰하기 위해 경두개방사선 사진과 ARCUSdigma II를 이용하였다. 경두개방사선 사진 촬 영결과 최대교두감합위에서 전방위치된 우측 과두가 관 찰되었으며, ARCUSdigma II를 이용하여 관찰한 개폐 구경로에서 조기접촉 및 사면활주를 관찰할 수 있었다.
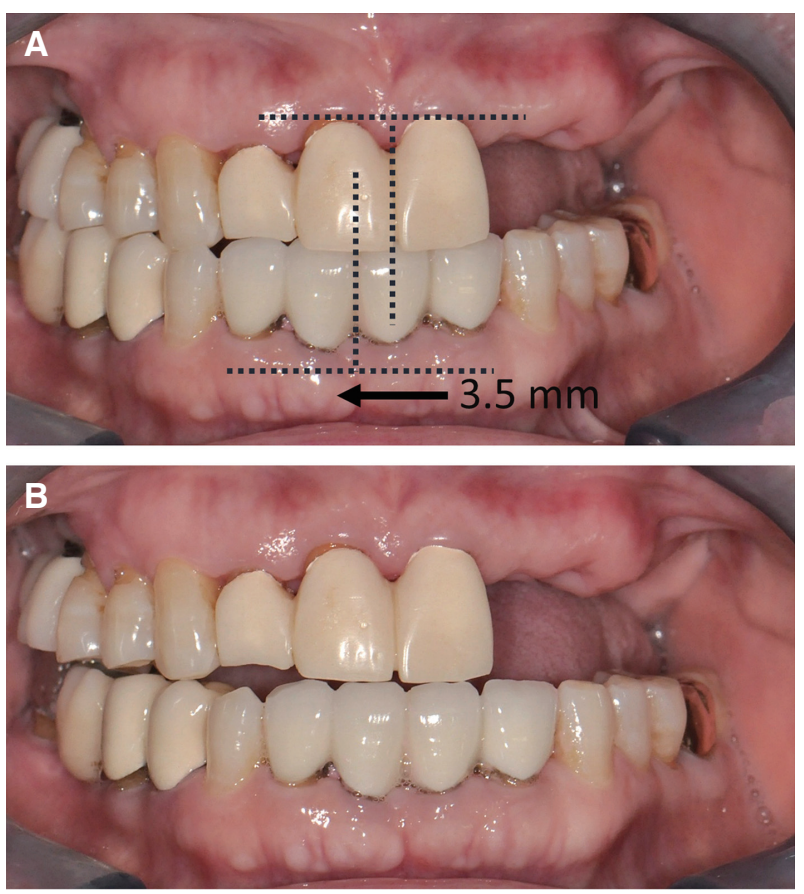

Fig. 3. (A) right mandibular shift on maximum intercuspation, (B) guided centric relation.

\section{2. 수직고경 및 보철 수복 공간 평가}

수직고경 감소 여부 평가는 안정시 악간공극, 발음, 안 모평가, 마모의 기왕력, 구치부 지지상실 여부 등을 분 석하여 결정하였다. 안정시 악간공극 평가 시 최대교두 감합위보다 $4 \mathrm{~mm}$ 의 교합간 거리가 증가 하였으며, ' $\mathrm{S}$ ' 발음평가 시 상악 절치 설면과 하악전치 절단면 사이에 최소 이개가 관찰되었다. 안모 평가 시 수직고경 감소와 관련된 양상은 관찰할 수 없었고 Willis법, $\mathrm{McGee}$ 법에 따른 안모분석비율(Fig. 4)은 정상 범주였다. 환자는 내 원하기 전까지 구치부 지지상실을 경험한 적 없었고, 치 아가 마모된 흔적은 관찰할 수 없었다. 이상의 평가요소 들을 종합하였을 때 수직고경의 감소는 없거나 미미한 정도로 진단할 수 있었다.

정확한 진단 및 임시수복물의 제작을 위하여 중심위 를 채득하여 반조절성 교합기에 모형을 부착하였다. 중 심위로 부착된 모형상에서 관찰시 좌측 상악중절치에 서 가장 먼저 조기접촉이 관찰되었다. 모형상에서 전 치, 소구치 및 대구치 부위를 순차적으로 교합조정하 여 편향된 교합 접촉을 제거한 후 중심위와 일치하는 최

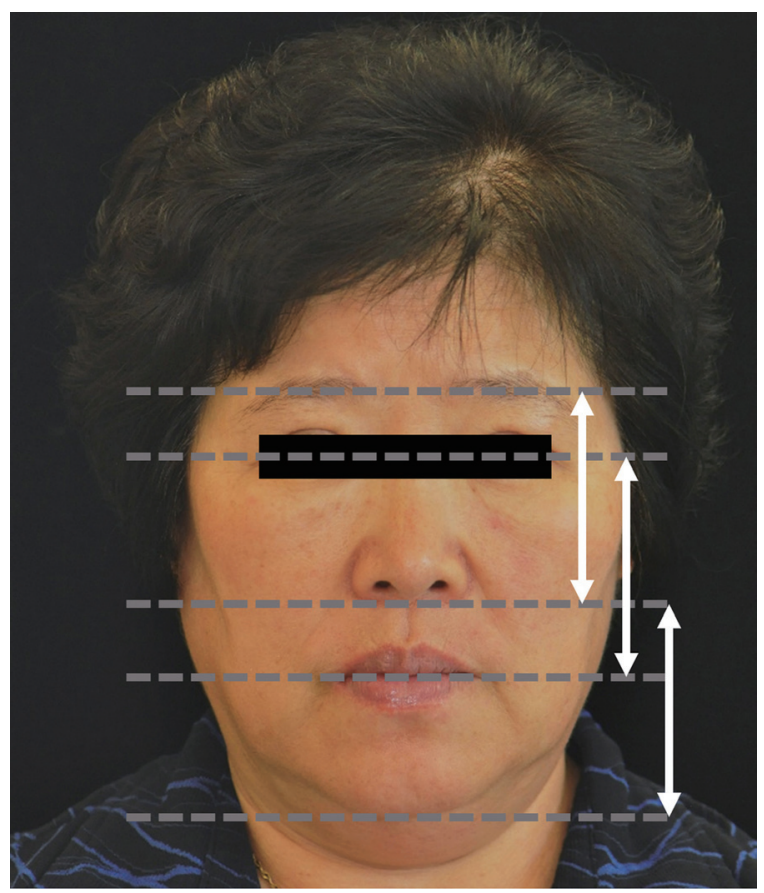

Fig. 4. Vertical dimension evaluation. 
대교두감합위를 획득하였다. 진단납형을 통해 1 차 임 시수복물을 제작(Fig. $5 \mathrm{~B})$ 하였으며 상악 좌측 무치악 부위의 수복공간은 충분하였다. 경두개방사선 사진과 ARCUSdigma II를 이용하여 변화된 과두위치와 사면활 주가 제거된 개폐구경로를 확인하였다.

\section{3. 교합평면 및 주위조직 평가와 치료계획}

우측 구치부의 급격한 스피만곡은 상하악 보철물의 재제작 및 임플란트 식립을 통하여 수정하기로 하였으 며 이차우식이 존재했던 상하악 전치부의 보철물 역시 재제작 하기로 결정하였다. 상악 좌측 무치악 부위도 역 시 임플란트 식립을 통하여 고정성 보철물로 수복하기 로 결정하였다. CBCT로 무치악 부위의 가용골 평가 시 상악 좌측 측절치 부위의 가용골이 매우 부족하여 견치, 소구치, 대구치 부위에 임플란트를 식립하고 상악 좌측 측절치는 캔틸레버로 수복하기로 결정하였다. 본 증례 에서 우측의 상하악 견치는 건전하고 위치관계가 양호 하여 상호보호교합을 부여하기로 하였으며, 좌측은 상 악의 모든 치아가 임플란트였고 상악 좌측 측절치가 캔 틸레버이기 때문에 군기능 교합을 부여하기로 하였다.
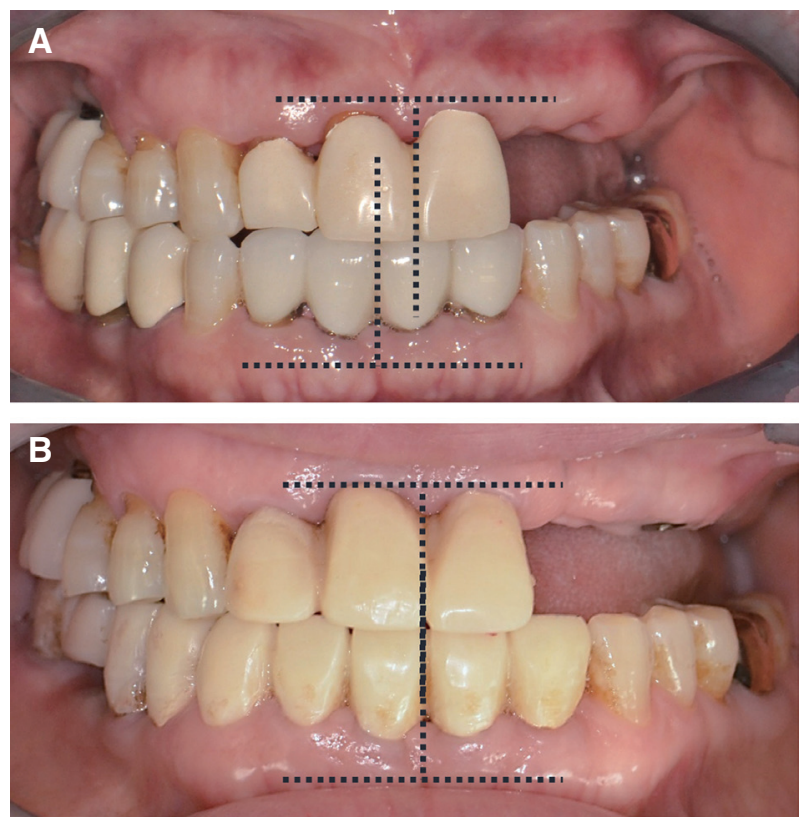

Fig. 5. (A) initial examination, (B) corrected mandibular position using 1st provisional prosthesis.

\section{4. 보철 수복 과정}

1차 임시수복물을 통해 획득한 최대교두감합위를 기 준으로 대합치의 작업교두에 임플란트의 중심축이 위 치하도록 무치악 부위에 임플란트를 식립하였다(Fig. 6) 임플란트의 골유착이 완료된 후 2차 임시 수복물 제 작을 위하여 인상을 채득하고 bonnet crown을 이용하 여 악간관계 기록을 채득하였다. 2 차 임시수복물 제작 후 우측의 상호보호교합, 좌측의 군기능 교합을 부여하 였으며, 상악 좌측 측절치 부위는 교합력이 작용하지 않 도록 조정하였다(Fig. 7). 2차 임시수복물 제작 후 6주 의 평가기간을 가졌다. 환자는 불편감을 호소하지 않았 으며 저작 및 발음 상의 문제도 없었기 때문에 최종수복 을 진행하였다. 실리콘 인상재(Examixfine, GC, Tokyo, Japan)를 이용하여 최종 보철물을 위한 인상을 채득하였 다. 상악 제 2 대구치에는 제 1 대구치와의 수직적 위치차
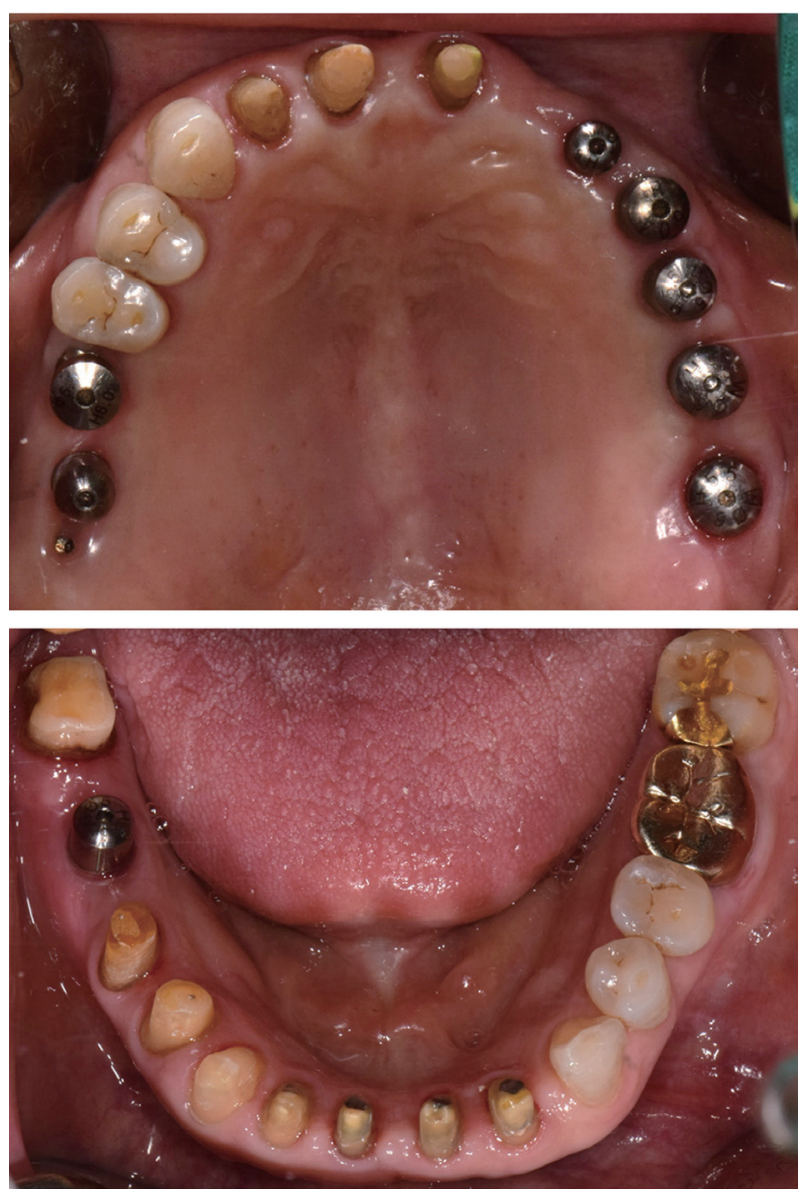

Fig. 6. Re-evaluation for prosthetic and occlusal design after implant placement and teeth preparation. 

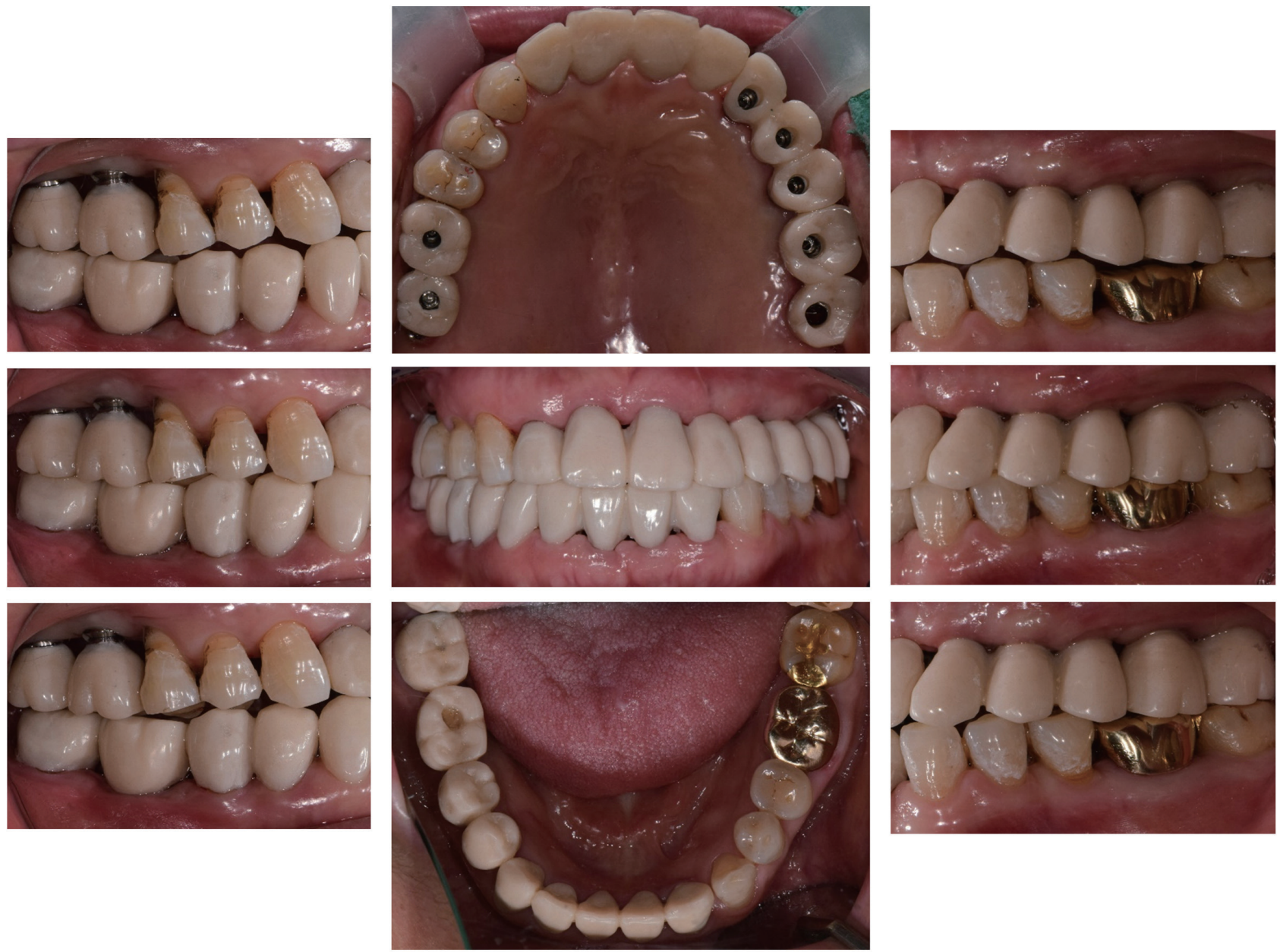

Fig. 7. Stable centric and lateral occlusal contact establishment using 2 nd provisional prosthesis.

이를 보상하기 위하여 $2 \mathrm{~mm}$ 의 지대주를 연결하였고, 그 외의 모든 임플란트는 임플란트 수준(implant level)에서 보철물을 제작하였다.

Type IV 초경석고를 이용하여 주모형을 제작한 후, 임 시수복물과 안와점(orbitale)을 기준으로 안궁이전을 시 행하고 실리콘 교합인기재(Futer D, Kettenbach GmbH \& Co. KG, Eschenburg, Germany)를 이용하여 악간 관 계를 기록하였다. 임시수복물 장착 상태의 모형과 주모 형을 교차부착하여 교합기에 부착하였다. 부착된 주모 형에 최종 수복물의 형태대로 납형을 제작하고, 되깍이 (cut-back)를 시행하였으며 적합도 및 형태 확인 후 도재 를 축성하였다(Fig. 8). 전치부와 소구치는 금속도재관으 로 제작하였으며 대구치는 금관으로 제작하였다. 하악 전치와 소구치는 도재 교합면, 그 외는 금 교합면을 부 여하였다.
전방 유도 인기 장치(anterior programming device)를 이용하여 중심위를 기록한 후 맞춤트레이를 이용한 픽 업인상을 채득하여 진료실 재부착을 시행하였다. 교합 조정 후 최종 고정성 보철물을 완성하였다(Fig. 9). 최종 보철물은 임시수복물과 동일하게 우측은 상호보호교합, 좌측은 군기능교합을 형성하였다.

1 개월 후 평가에서 구강위생은 양호하였고 교합, 저 작, 발음, 심미, 악관절 관련 불편감은 없었다. 3 개월 후 평가에서 파노라마(Fig. 10)와 경두개 방사선 사진(Fig. 11)을 촬영하여 초진과 비교 시 안정적으로 유지되고 있 는 치조골 수준과 약간 후방변위된 과두위치를 확인하 였다. ARCUSdigma II를 이용하여 1차 임시수복물을 착 용한 시점과 동일한 개폐구경로를 확인하였다(Fig. 12A, $12 \mathrm{~B})$. 개폐구경로는 초진과 비교 시 사면활주가 제거되 었고 폐구각이 작아지는 변화(Fig. 12C,12D)를 보였다. 

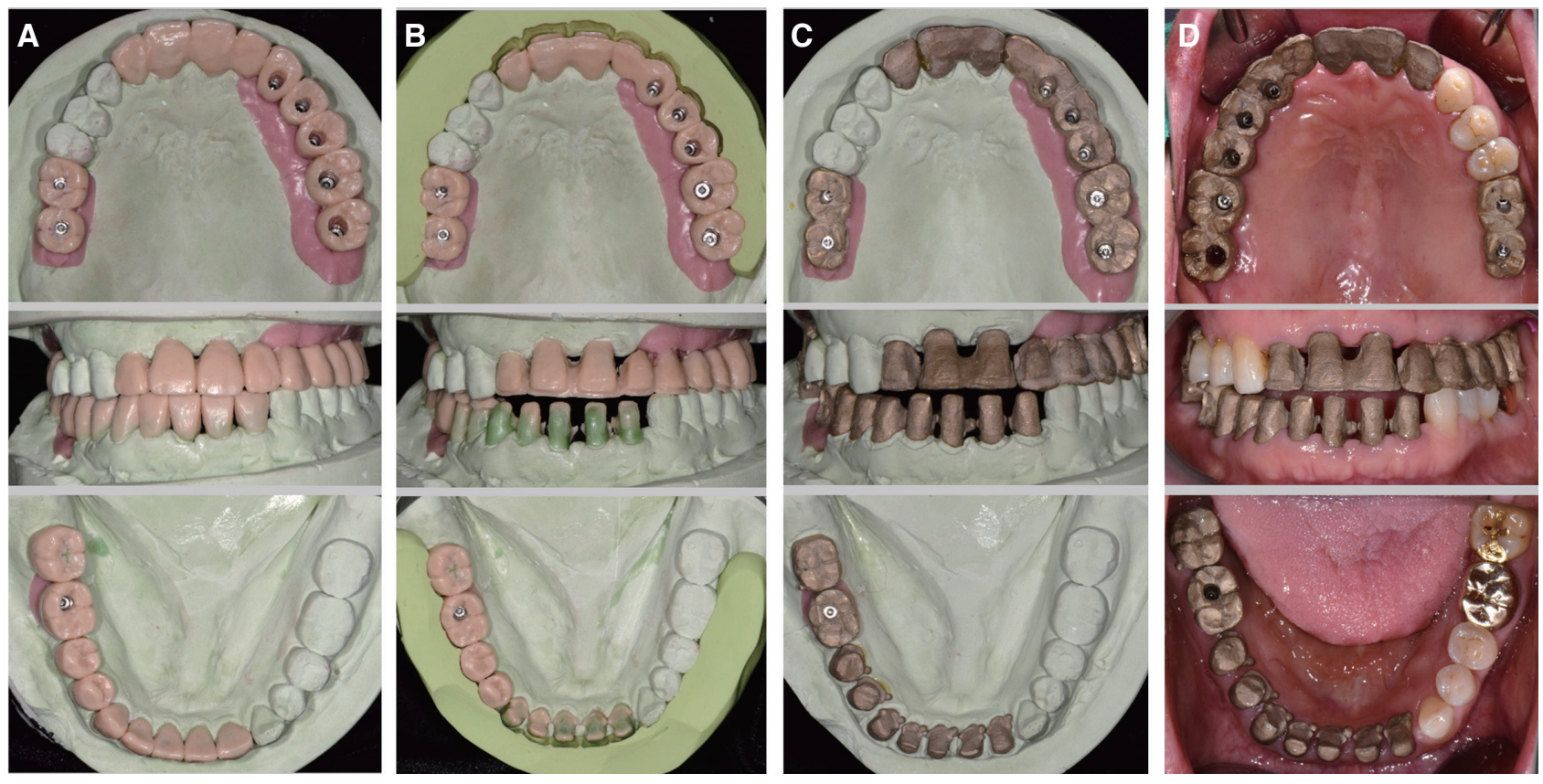

Fig. 8. (A) Full-contour wax-up, (B) Cut-back, (C) Metal coping fabrication, (D) Try-in.
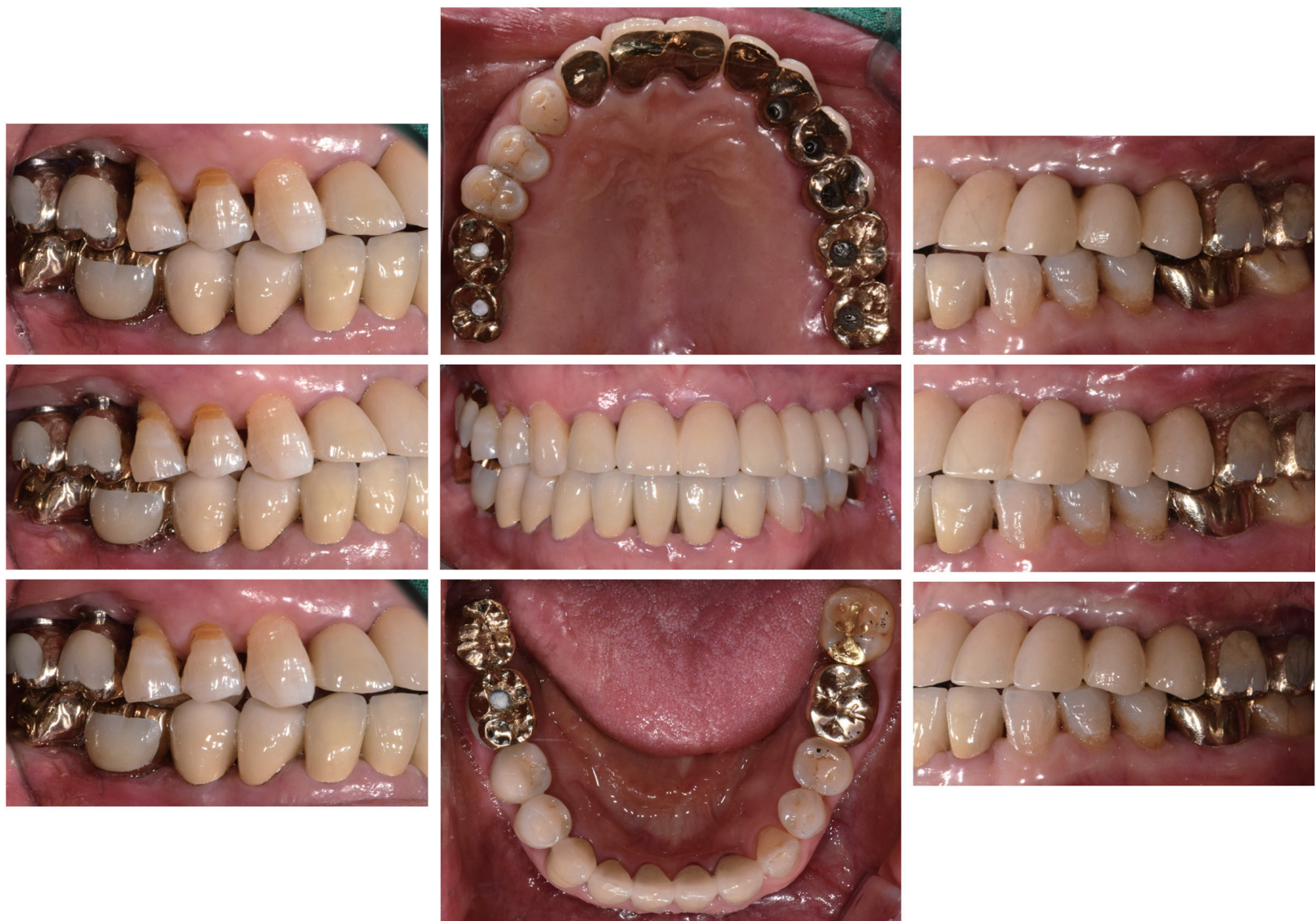

Fig. 9. Definitive prosthesis showing harmonized occlusal relationship. 


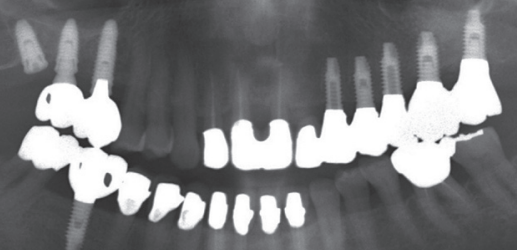

Fig. 10. Panoramic radiograph at 3 month follow-up.
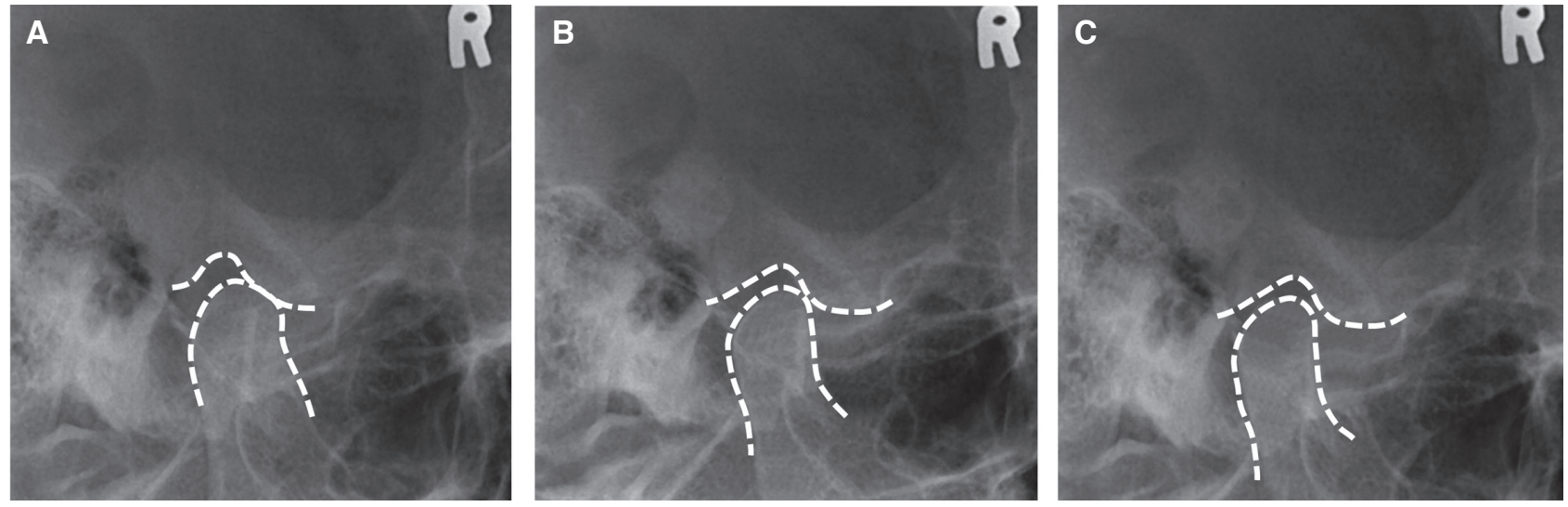

Fig. 11. Transcranial view of right mandibular condyle. (A) At initial examination, (B) During provisionalization, (C) After Wearing definitive prosthesis.
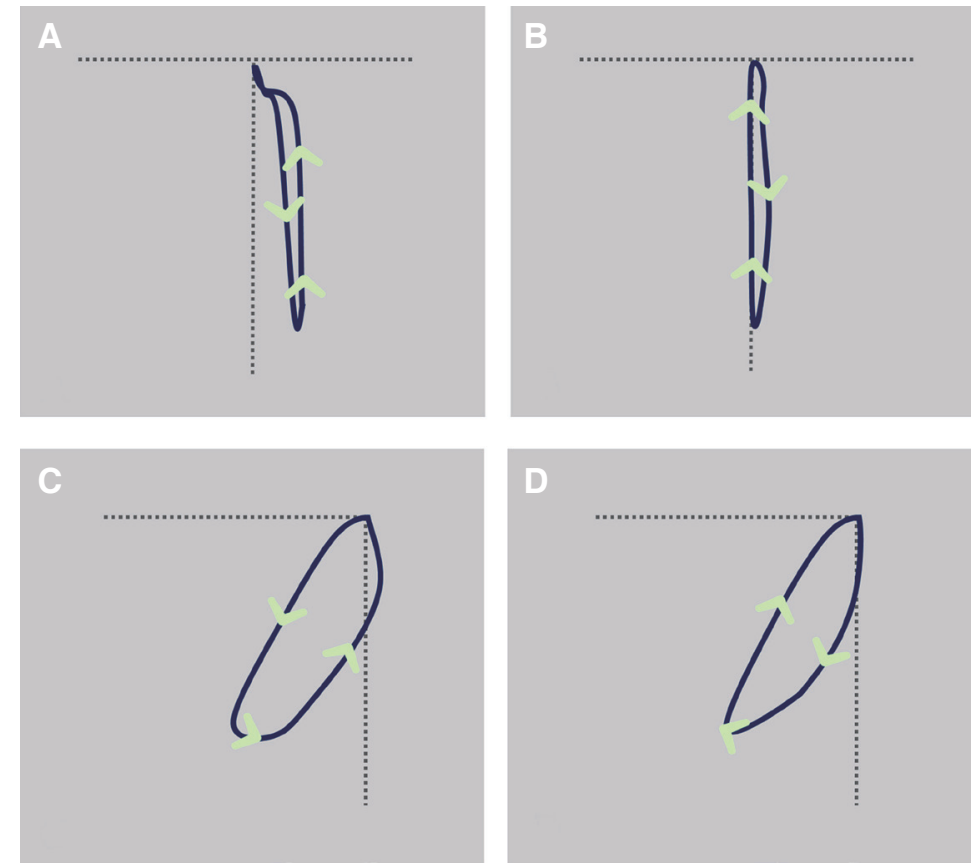

Fig. 12. Opening and closing path traced by ARCUSdigma II (A) Frontal view on initial examination, (B) Frontal view after definitive prosthesis delivery, (C) Sagittal view on initial examination, (D) Sagittal view after definitive prosthesis delivery. 


\section{고찰}

중심위와 최대교두감합위의 불일치를 보이는 환자는 임상적 증상과 상황에 따라 비생리적인 교합양상을 제 거해 주는 교합치료가 필요할 수 있다. 본 증례의 환자 는 중심위와 최대교두감합위의 불일치가 수평적으로 약 $3.5 \mathrm{~mm}$ 로 관찰되었고, 치주 및 보존적 문제 때문에 다 수의 보철물 재제작이 필요한 상태였다. 따라서 광범위 한 보철수복과 함께 중심위와 최대교두감합위를 일치시 켜 생리적인 교합양상과 기능을 회복해 주었다.

수복 후 ARCUSdigma II를 이용하여 관찰한 개폐구 경로는 초진과 비교 시 사면활주가 제거되었고 폐구각 이 작아지는 변화를 보였다. 시상면을 기준으로 개폐구 경로를 비교해 보면, 초진 시에는 개구 경로에 비하여 폐구 경로가 전방에 위치하고 있었으나 수복 후에는 이 러한 양상이 반대로 변화하여 개구 경로가 폐구 경로보 다 전방에 위치하고 있다. 수복 후 폐구각이 작아지는 변화는 이러한 양상의 변화 때문인 것으로 사료된다. 초 진 시의 개폐구 양상과 같이 폐구 경로가 개구 경로보 다 전방에 위치하는 경우를 Ehrlich 등'은 "protrusion pattern' 이라고 하였으며 전치부의 마모와 병적이동을 유발한다고 하였다. 또한 Yoshida 등 $^{10}$ 은 폐구각이 작아 질수록 저작효율이 증가함을 관찰하였다. 따라서 본 증 례에서 수복 후 폐구각이 감소한 것과 개폐구 경로가 변 화한 양상은 환자의 구강건강에 긍정적으로 작용할 것 으로 판단된다.

본 증례의 캔틸레버 수복물은 부족한 가용골을 고려 하여 설계되었으며 응력분산의 시점에서 불리한 구조이 다. 수복물에 저작력이 작용하는 지점이 임플란트의 중 심축에서 멀어질수록 임플란트에 가해지는 응력의 양은 증가하게 되므로 ${ }^{11}$ 캔틸레버로 연결된 임플란트는 증가 된 변연골 흡수의 위험성을 가진다. 그러나 교합력의 직 접적인 작용을 차단하고 적절히 설계된 캔틸레버 수복 물은 일반적인 형태의 임플란트 수복물과 동일한 예후 를 보일 수도 있다. 임플란트의 캔틸레버 수복물에 대한 체계적 문헌고찰에서 캔틸레버 수복물의 변연골 흡수량 이 일반적인 형태의 임플란트 수복물과 유의한 차이가 나지 않음이 밝혀졌다. ${ }^{12,13}$ 이는 가용골이 부족하거나 해 부학적인 구조에 의해 임플란트 식립에 제한이 있을 때 캔틸레버 수복물을 설계하는 것이 치료의 한 방법이 될 수 있음을 의미한다. 하지만 캔틸레버 수복물에서 잦은 도재의 파절과 나사풀림이 보고되고 있음을 간과해서는
안된다. ${ }^{13}$ 본 증례의 캔틸레버 수복물은 금속도재관으로 잦은 도재파절의 위험성을 배제할 수 없다. 3 개월까지 도재파절 및 나사풀림은 관찰되지 않았지만 추후 잦은 도재파절이 관찰된다면 지르코니아 소재의 수복물로 교 체하는 방법을 고려할 수 있을 것이다. 한편 본 증례의 캔틸레버 수복물은 심미성의 시점에서는 유리하게 작 용할 수 있다. 인공치와 자연치 사이의 치간유두 높이가 임플란트와 자연치 사이의 치간유두보다 약 $2 \mathrm{~mm}$ 높게 형성되기 때문에 ${ }^{14}$ 중절치와 측절치 사이 치간유두 형성 에 있어서는 캔틸레버 수복물이 더 유리하게 작용할 것 이다.

본 증례의 초진과 보철수복 후의 개폐구경로를 비교 해보면 의도했던 대로 사면활주가 제거되었음을 관찰 할 수 있다. 이러한 치료결과는 정확한 중심위 기록을 채득함으로써 이루어질 수 있었다. 그러나 이와 같은 교 합 재구성을 통해 제거된 사면활주는 시간이 지난 후 재 발할 가능성이 있다. ${ }^{15}$ 사람을 대상으로 주기적인 교합 조정을 시행한 실험에서 4 년 후 실험군의 약 $45 \%$ 정도 에서 사면활주가 재발되었다. ${ }^{16}$ 비록 아무런 교합조정을 시행하지 않은 대조군의 $80 \%$ 에 비해서는 감소된 수치 였지만, 임상가는 교합조정 후 사면활주가 재발하는 경 향이 있음을 인지하고 있어야 한다. 본 증례에서는 수복 후 3개월까지 주기적인 교합조정을 시행하여 안정된 교 합을 획득하였으며 아직까지 병적인 증상은 발견되지 않았다. 하지만 계속적으로 주기적인 검진 및 교합조정 이 필요할 것이다.

\section{결론}

중심위와 최대교두감합위의 불일치는 악관절 질환과 치아 및 치주조직의 문제를 야기할 수 있으며 증상에 따 라 교합조정 혹은 광범위한 보철수복을 통한 교합재구 성을 필요로 한다. $3.5 \mathrm{~mm}$ 의 사면활주를 보이는 환자에 서 정확한 중심위 기록을 통한 보철수복을 시행하여 중 심위와 최대교두감합위를 일치시켰으며 개폐구경로와 과두위치의 변화를 확인하였다. 사면활주의 재발을 방 지하기 위하여 주기적인 검진 및 교합조정이 필요할 것 으로 예상된다.

\section{Orcid}

Seung-Sik Choo http://orcid.org/0000-0001-5721-6222 
Yoon-Hyuk Heo http://orcid.org/0000-0003-4072-5199

Lee-Ra Cho http://orcid.org/0000-0003-3989-2870

Chan-Jin Park http://orcid.org/0000-0003-4734-214X

\section{References}

1. The glossary of prosthodontic terms. J Prosthet Dent 2005;94:10-92.

2. Pullinger AG, Seligman DA, Gornbein JA. A multiple logistic regression analysis of the risk and relative odds of temporomandibular disorders as a function of common occlusal features. J Dent Res 1993;72:968-79.

3. Landi N, Manfredini D, Tognini F, Romagnoli M, Bosco M. Quantification of the relative risk of multiple occlusal variables for muscle disorders of the stomatognathic system. J Prosthet Dent 2004;92:190-5.

4. Branschofsky M, Beikler T, Schäfer R, Flemming TF, Lang H. Secondary trauma from occlusion and periodontitis. Quintessence Int 2011;42:515-22.

5. Harrel SK, Nunn ME. The association of occlusal contacts with the presence of increased periodontal probing depth. J Clin Periodontol 2009;36:1035-42

6. Brandini DA, Trevisan CL, Panzarini SR, Pedrini D. Clinical evaluation of the association between noncarious cervical lesions and occlusal forces. J Prosthet Dent 2012;108:298-303.

7. Troeltzsch M, Troeltzsch M, Cronin RJ, Brodine AH, Frankenberger R, Messlinger K. Prevalence and association of headaches, temporomandibular joint disorders, and occlusal interferences. J Prosthet Dent 2011;105:410-7.

8. Dawson PE. Functional occlusion: from TMJ to smile design. St. Louis; CV Mosby; 2007. p. 4-9.

9. Ehrlich J, Hochman N, Yaffe A. The masticatory pattern as an adjunct for diagnosis and treatment. J Oral Rehabil 1992;19:393-8.

10. Yoshida E, Fueki K, Igarashi Y. Association between food mixing ability and mandibular movements during chewing of a wax cube. J Oral Rehabil 2007;34:791-9.

11. Park JM, Kim HJ, Park EJ, Kim MR, Kim SJ. Three dimensional finite element analysis of the stress distribution around the mandibular posterior implant during non-working movement according to the amount of cantilever. J Adv Prosthodont 2014; 6:361-71.

12. Aglietta M, Siciliano VI, Zwahlen M, Brägger U, Pjetursson BE, Lang NP, Salvi GE. A systematic review of the survival and complication rates of implant supported fixed dental prostheses with cantilever extensions after an observation period of at least 5 years. Clin Oral Implants Res 2009;20:44151.

13. Zurdo J, Romão C, Wennström JL. Survival and complication rates of implant-supported fixed partial dentures with cantilevers: a systematic review. Clin Oral Implants Res 2009;20 Suppl 4:59-66.

14. Salama MA, Salama H, Garber DA. Guidelines for aesthetic restorative options and implant site enhancement: the utilization of orthodontic extrusion. Pract Proced Aesthet Dent 2002;14:125-130.

15. Hellsing G. Occlusal adjustment and occlusal stability. J Prosthet Dent 1988;59:696-702.

16. Kirveskari P. Assessment of occlusal stability by measuring contact time and centric slide. J Oral Rehabil 1999;26:763-6. 


\section{비생리적인 최대교두감합위의 교합재구성을 통한 수정}

\section{추승식, 허윤혁, 조리라, 박찬진*}

강릉원주대학교 치과대학 치과보철학교실 및 구강과학연구소

중심위에서 벗어나 있는 최대교두감합위는 상하악 치아의 조기접촉 및 사면활주의 직접적인 원인이며, 악관절 내장증, 치아마모, 치주질환 등을 일으킬 수 있다. 그러므로 광범위한 보철수복이 필요한 환자에서 중심위와 최대교두감합위의 불일치가 존재하는 경우 반드시 이를 제거하여 생리적인 교합양식을 회복해야 한다. 본 증례의 환자는 초진 시 약 3.5 $\mathrm{mm}$ 의 사면활주와 다수의 우식 및 중등도의 치주질환을 않고 있었다. 보철수복을 통해 기능 및 심미성을 회복하는 동 시에 중심위와 최대교두감합위를 일치시켜 사면활주를 제거하였으며, ARCUSdigma II와 경두개 방사선 사진을 이용 하여 생리적인 위치로 수정된 하악위와 변화된 개폐구 경로를 관찰하였다.

(구강회복응용과학지 2015;31 (3) :273-82)

주요어: 중심위; 최대교두감합위; 사면활주; 교합재구성

*교신저자: 박찬진

(25457)강원도 강릉시 죽헌길 7 강릉원주대학교 치과대학 치과보철학교실

Tel: 033-640-3153 | Fax: 033-640-3103 | E-mail: doctorcj@gwnu. ac. kr

접수일: 2015년 6월 29일 | 수정일: 2015년 6월 30일 | 채택일: 2015년 7월 14일 